Available online at GSC Online Press Directory

GSC Biological and Pharmaceutical Sciences

e-ISSN: 2581-3250, CODEN (USA): GBPSC2

Journal homepage: https://www.gsconlinepress.com/journals/gscbps

(RESEARCH ARTICLE)

\title{
Influence of environmental factors and exogenous nitrogen on nitrogen fixation by intact thallus and excised cephalodia of Peltigera aphthosa
}

\author{
Ngerebara NN, Amadi LO ${ }^{*}$ and Ekiyor HT \\ ${ }^{1}$ Department of Science Laboratory Technology, School of Applied Sciences, Kenule Beeson Saro-Wiwa Polytechnic; P.M.B. \\ 20, Bori. \\ 2 Department of Microbiology, Faculty of Science, Rivers State University, P.M.B 5080, Nkpolu-Oroworukwo, Port \\ Harcourt, Nigeria.
}

Publication history: Received on 27 September 2020; revised on 04 October 2020; accepted on 06 October 2020

Article DOI: https://doi.org/10.30574/gscbps.2020.13.1.0313

\begin{abstract}
The present study investigates the effects of various abiotic environmental factors: air humidity, moisture content, oxygen and exogenously supplied nitrogen on acetylene reduction by intact thallus and excised cephalodia of Peltgera aphthosa. Intact thallus and excised cephalodia of Peltigera aphthosa were incubated at various conditions of air humidity, moisture contents, oxygen tensions, and addition of exogenous nitrogen, and comparative nitrogen fixation by the intact thallus and excised cephalodia was used as a method for assessment. Acetylene reduction (nitrogen fixation) was enhanced at conditions of lowered oxygen tension and at initial addition of nitrogen to the medium. However, prolonged incubation of Peltigera aphthosa in the medium with combined nitrogen addition resulted in fluctuation of nitrogenase synthesis. Acetylene reduction rates were stimulated in an atmosphere of $100 \%$ relative humidity (RH) and moisture content range of 570-620\% of dry weight of Peltigera aphthosa. The decrease of nitrogenase activity measurable by acetylene reduction of thallus after prolonged incubation in the medium with combined nitrogen addition shows susceptibility of the symbiosis (lichen) since the thallus showed signs of disintegration at this time. Furthermore, air humidity and moisture content of the thallus influenced nitrogenase synthesis of Peltigera aphthosa considerably on separation of cephalodia such approach decreased nitrogenase activity and also elicited differences in their response to the various treatments. Applicability of this technology would enhance plant sustainability and yield in agricultural farms.
\end{abstract}

Keywords: Peltigera aphthosa; Moisture content; Relative humidity; Nitrogenase activity; Exogenous nitrogen

\section{Introduction}

Knowledge of nitrogen fixation by blue-green algae has increased substantially within resent years as new groups of nitrogen-fixing algae have been discovered; detailed physiological and biochemical studies on the inter-relations of metabolic processes such as nitrogen-fixation, photosynthesis and respiration have been carried out as well as the ecological importance of the group has been recognized and confirmed [1,2,3,4,5,6,7]. Again, the relationship between phycobiont (blue-green algae) and mycobiont (fungi) of lichen symbiosis association in nitrogen-fixation has been obtained by several investigators [8].

However, the ecological significant of nitrogen fixation by lichen has only recently been paid greater attention in nitrogen deficient arctic tundra where these organisms are very abundant. At the tundra nitrogen fixation by Stereocaulon and Peltigera species are considered to be of particular importance in the nitrogen budget [9,10]. These

\footnotetext{
* Corresponding author: Amadi LO; Phone: 08033394806.

Department of Microbiology, Rivers State University, P.M.B 5080, Nkpolu-Oroworukwo, Port Harcourt, Rivers State, Nigeria.
} 
associations are widespread on glacial drift on Iceland where they vigorously fixed nitrogen, moreover, in Northern Finland, Nephroma, Solorina, and Stereocaulon species are the principal $\mathrm{N}_{2}$ fixing lichen [11,12]. In parts of the subarctic tundra of Sweden, species of Nephroma, Peltigera and Stereocaulon cover ground completely because of their ecological importance [13].

This present study presents data on effects of combined nitrogen addition, air humidity, moisture content and oxygen tension on acetylene reduction (nitrogen fixation) by Peltigera aphthosa subjected to laboratory investigation.

\section{Material and methods}

\subsection{Collection of lichen and microscopy}

The lichen, Peltigera aphthosa was collected from wet and steep Isiama forest in Andoni Local Gov't Area of Rivers State of Nigeria. This area was dominated by mosses, ferns and grasses. The lichen samples were kept in glass vials covered with transparent plastic foil to prevent desiccation. Prior to assay, all adhering materials were carefully removed with forceps and the lichen thalli rinsed in distilled water. In all the tests lichen discs with or without cephalodia were used. Lichen discs were punctured from the thallus lobes $(9,14$, or $16 \mathrm{~mm})$ and cephalodia were dissected off with two sharp edge needles under a low power binocular microscope.

\subsection{Determination of acetylene reduction}

The method used to determine acetylene reduction in algal cells was that of steward as was modified by Edward [14]. However, the gas phase was not removed prior to the injection of acetylene nor was the reaction terminated by addition of trichloroacetic acid. Thallus discs and excised cephalodia were placed in glass serum bottles with a capacity of 7 or $27 \mathrm{ml}$ and fitted with serum liners. The rest materials were exposed to atmosphere containing $10 \%$ acetylene in air for 30 to 60 minutes for the detection of ethylene formation, gas samples were taken and injected into a Varian-Aerograph model 1200-1 gas chromatograph.

Triplicate samples of lichen dices were incubated in ASM medium with or without an addition of $1 \mathrm{~g} \mathrm{KNO} \mathrm{K}^{-1}$ at $20^{\circ} \mathrm{C}$ and 8000 lux to asses for effect of combined nitrogen addition. Peltigera aphthosa thallus were incubated in ASM medium at various relative humidities and moisture contents for about 74 hours. Then, Peltigera aphthosa samples were incubated in ASM medium at $20^{\circ} \mathrm{C}$ and 8000lux under a gas phase of $\mathrm{Ar} / \mathrm{O}_{2} / \mathrm{CO}_{2} \mathrm{l}$, for about 7 hours and the effects of aerobic and anaerobic conditions on the acetylene reduction by Peltigera aphthosa observed.

\section{Results}

The results of acetylene reduction by intact lichen discs, isolated cephalodia and lichen discs are presented in Figure 1. The effect of nitrate on acetylene reduction by Peltigera apthosa are presented in Table 1 . The influence of air humidity and addition of water on acetylene reduction by intact discs of Peltigera aphthosa is presented in Figure 2. The moisture content of the Peltigera aphthosa thallus when incubated at various relative humidites and after addition of water are presented in Table 2. Effects of aerobic and anaerobic conditions on the acetylene reduction by Peltigera aphthosa incubated at $20^{\circ} \mathrm{C}$ and 8000lux under a gas phase of $\mathrm{Ar} / \mathrm{O}_{2} / \mathrm{CO}_{2}$ is present in Figure 3.

Table 1 Effect of nitrate on acetylene reduction by Peltigera aphthosa

\begin{tabular}{llll}
\hline $\begin{array}{l}\text { Incubation } \\
\text { Days }\end{array}$ & Nmoles $\mathbf{C}_{2} \mathrm{H}_{4} \mathbf{g d}+\mathbf{w}^{-\mathrm{I}}-\mathbf{h}^{-\mathbf{1}}$ & $\begin{array}{l}\text { Increase or decrease on } \\
\text { addition (\%) }\end{array}$ \\
\hline & + Nitrate & -Nitrate \\
\hline 0 & $28.5 \pm 8.1$ & $27.5 \pm 3.3$ & +3 \\
6 & $72.0 \pm 11.7$ & $45.4 \pm 13.0$ & +62 \\
9 & $26.0 \pm 6.7$ & $20.3 \pm 6.0$ & +27 \\
11 & $23.1 \pm 6.0$ & $13.0 \pm 4.6$ & +78 \\
14 & $5.4 \pm 1.5$ & $11.4 \pm 2.6$ & -57 \\
\hline
\end{tabular}


Table 2 Water content of Peltigera aphthosa thallus when incubated at various relative humidities and after addition of water

\begin{tabular}{llll}
\hline RH & \multicolumn{2}{l}{ Water content \% } & Dry weight \\
\cline { 2 - 4 } \% & $\mathbf{0 h}$ & $\mathbf{5 2 h}$ & $\mathbf{7 4 h}$ \\
\hline 100 & $340 \pm 20$ & $242 \pm 14$ & $573 \pm 106$ \\
97.5 & $366 \pm 11$ & $265 \pm 8$ & $635 \pm 66$ \\
87.0 & $406 \pm 22$ & $149 \pm 10$ & $609 \pm 37$ \\
75.5 & $440 \pm 16$ & $129 \pm 12$ & $631 \pm 21$ \\
\hline
\end{tabular}

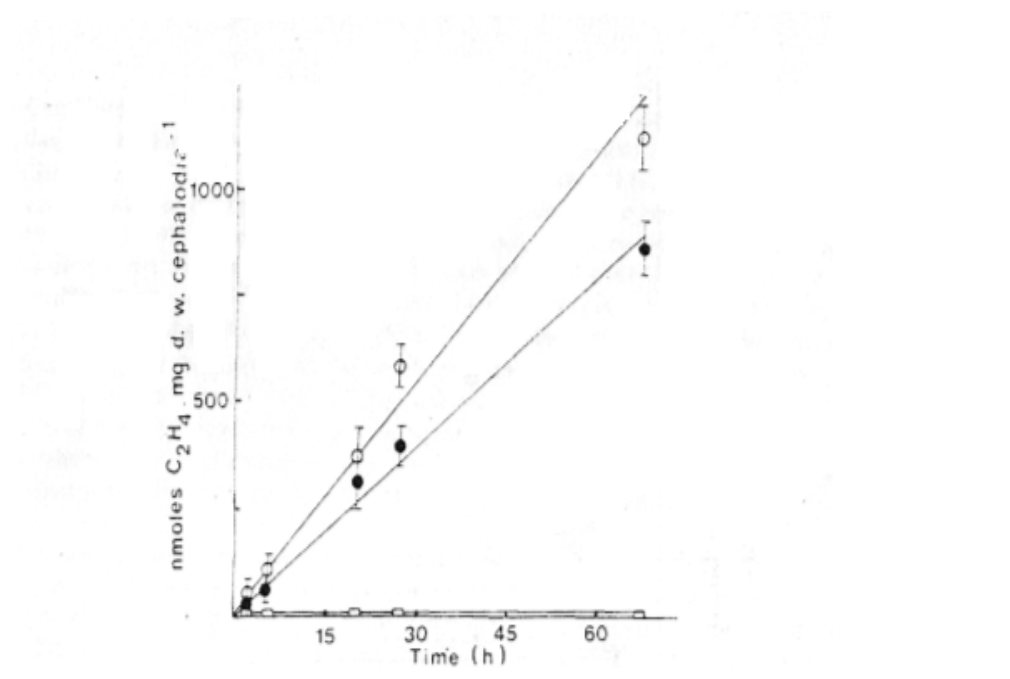

Figure 1 Acetylene reduction by intact lichen discs (0). isolated cephalodia (O) and lichen discs with cephalodia detached (0) of Peltigera aphthosa. Light intensity was 8000 lux and temperature $20^{\circ} \mathrm{C}$. Each point is the mean of triplicate determinations. Bars indicate \pm SE.

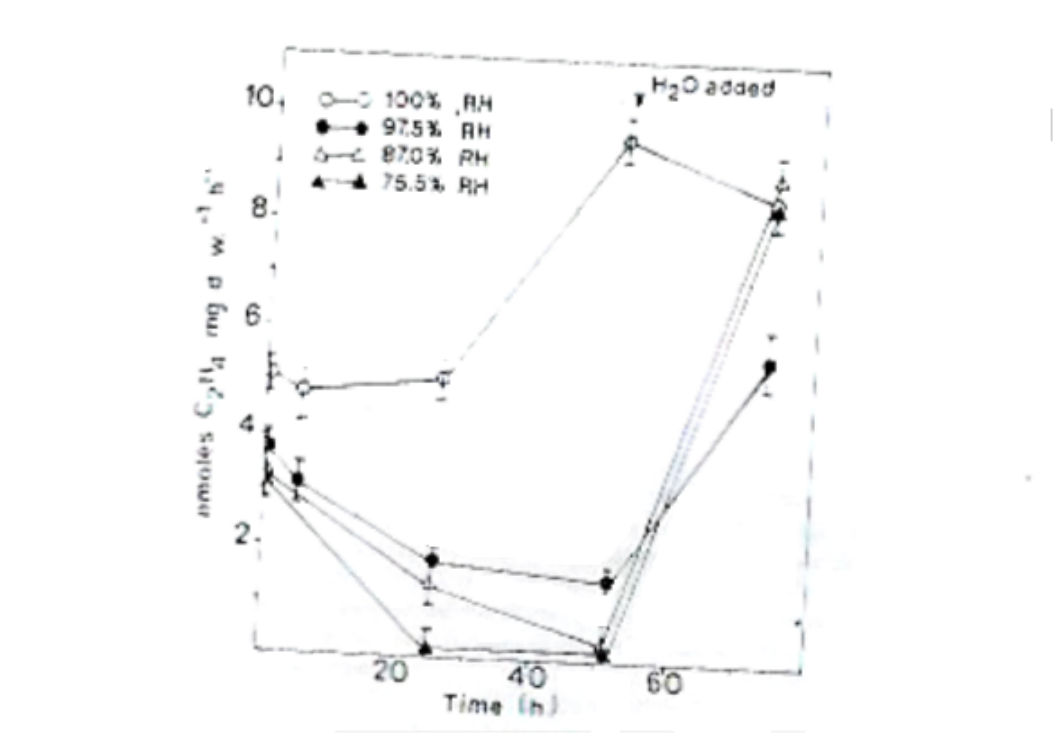

Figure 2 Influence of air humidity $(\mathrm{RH})$ and addition of water on acetylene by intact discs of Peltigera aphthosa. $1.0 \mathrm{ml}$ $\mathrm{H} 2 \mathrm{O}$ was added (arrow). Each value represents triplicate determinations. Bars indicate \pm SE. 


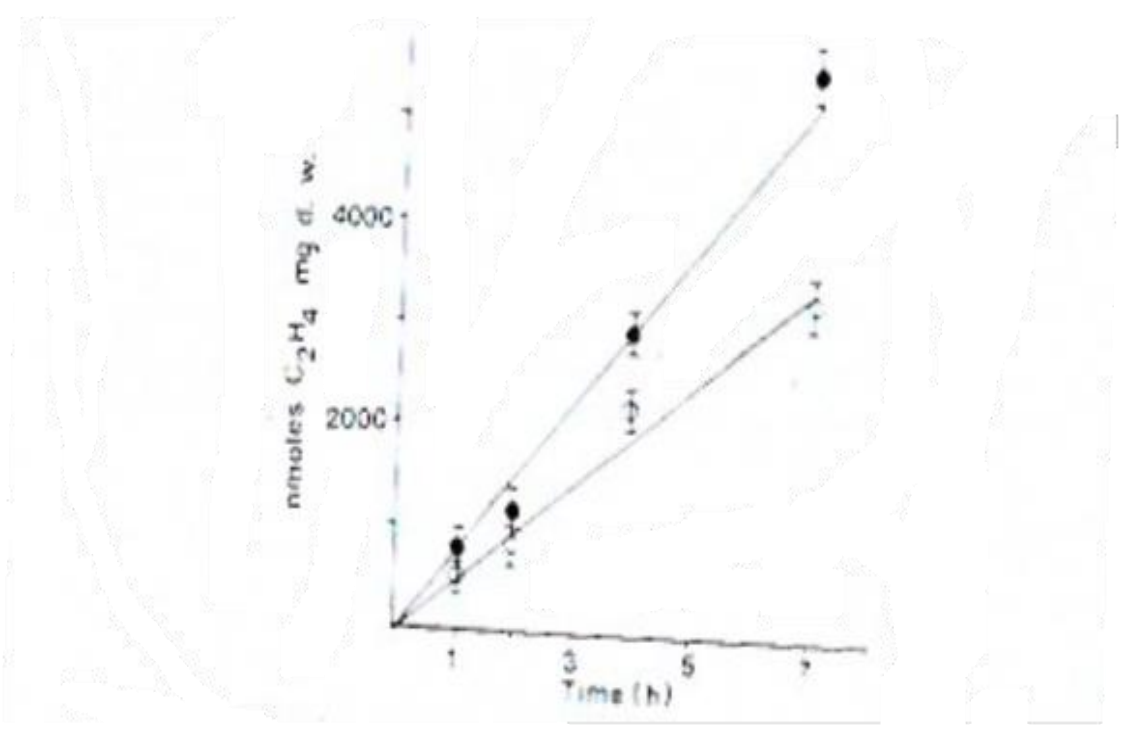

Figure 3 Efects of aerobic (0) and anaerobic (O) conditions on the acetylene reduction by Peltigera aphthosa. The samples were incubated at $20^{\circ} \mathrm{C}$ and 8000 lux under a gas phase of $\mathrm{Ar}_{2} / \mathrm{O}_{2} / \mathrm{CO}_{2}(77.96 / 22.00 / 0.4 \mathrm{v} / \mathrm{v})$ or $\mathrm{Ar} / \mathrm{CO} 2$ $(99.96 / 0.04 \mathrm{v} / \mathrm{v})$ respectively. Bar indicate $\pm \mathrm{SE}$.

\section{Discussion}

The ability of Peltigera aphthosa to reduce acetylene was checked in preliminary experiments. From Figure 1, the reduction of acetylene of intact thallus occurs at a linear rate at least over a 68-hour period. Reduction of acetylene by the separated cephalodia and absence of such activity in the lichen thallus without cephalodia indicates that the bluegreen phycobiont is the site of nitrogen fixation, which is in agreement with experiment using ${ }^{15} \mathrm{~N}$ [15]. The preliminary experiments also showed that the optimum light intensity for laboratory incubation was 8000lux, and this intensity was used for all subsequent experiments unless otherwise stated.

When Peltigera aphthosa discs, previously grown on elemental nitrogen, were incubated in a medium with combined nitrogen added $\left(1 \mathrm{gKNO}_{3} \mathrm{l}^{-1}\right)$ an increase of nitrogenase activity of up to $78 \%$ was noted (Table 1 ). This was, however followed by a 51\% decrease, after 14 days of incubation. In Peltigera aphthosa virtually all of the nitrogen fixed (97\%) by the cyanophyte is transported to the mycobiont. The addition of combined nitrogen would appear to enhance the metabolic activity of the green phycobiont and thus indirectly affect the activities of the other two symbionts. The decrease after 14 days shows the susceptibility of the symbiosis to any disturbance of the partners, since the thallus showed signs of disintegration at this time.

When discs of Peltigera aphthosa were incubated under a gas phase lacking oxygen $\left(\mathrm{Ar} / 0_{2} / \mathrm{CO}_{2} ; 99.96 / 0.04\right.$, v/v) the algal fixation activity was enhanced by about $60 \%$ after a 7 -hour incubation (Figure 3 ). These results agree with earlier findings stating that conditions of lowered oxygen tension favour the synthesis of oxygen-labile nitrogenase in the vegetative cells of blue-green algae [16,17,18] as well as with results of [19] for Peltigera aphthosa. However, the ecological implication of these results is not evident.

Air humidity and water content of the Peltigera aphthosa thallus markedly influence the acetylene reduction rates (Figure 2). Incubation of lichen materials in an atmosphere of $97.5 \% \mathrm{RH}$ or less, reduces the reduction rates, while a stimulation is found in an atmosphere of $100 \%$ humidity. After 52 hours of incubation the acetylene reduction levels approached zero in samples incubated at $87.0 \% \mathrm{RH}$ or less. The moisture content of the lichen materials was also determined. Initially there was increase in the moisture content between 330 and $430 \%$ (percent of dry weight), and declined in all samples and at a moisture content of $150 \%$ or less, the algae exhibited negligible reduction activity. A rapid recovery of acetylene reduction rates was however, detected on addition of water with the moisture content raising to $570-620 \%$ of dry weights.

\section{Conclusion}

There was profound influence of environmental factors such as air humidity and moisture content of the thallus on nitrogenase synthesis of Peltigera aphthosa on separation of cephalodia from the main thallus. Thus, separating the 
cephalodia from the main thallus decreased nitrogenase activity and also elicited differences in their response to the various treatments. Knowledge of this methodology and application would enhance plant sustainability and productivity in agricultural farms.

\section{Compliance with ethical standards}

\section{Acknowledgments}

The authors appreciate the efforts of Mr. Vincent, Gladstone C and Sunday, Chizoba I for logistics and technical assistance.

\section{Disclosure of conflict of interest}

Ngerebara, NN conceptualized and drafted the manuscript, Amadi, LO Proofread, corrected and formatted the manuscript whereas all authors financed and approved the final manuscript and declares no conflict of interest.

\section{References}

[1] White PW, Silver PH. Nitrogen fixation by free-living microorganisms. Cambridge University press. 2001; 471.

[2] Stephen OV, Linus OR. Nitrogen fixation in soils of Truelove low land. Northwest Territories. Can. J. Bot. 2002; 53: $1387-1399$.

[3] Ralph CT, Silvanus PV. Nitrogenase activity and photosynthesis in Plectonema boryanum. J. Bacteriol. 2003; 119: 255-265.

[4] Felix AG, Indubusi WJ. Nitrogen assimilation and metabolism in blue-green algae J. Bacteriol. 2004; 120: 235-249.

[5] Fine bone OG, Kate NM. Canopy lichens with blue green algae: a Nitrogen source in a Columbian rain forest. Ecology. 2005; 56: 1176-1184.

[6] Cornillus RC, Cornell PC. Nitrogen fixation by lichens on glacial drift in Iceland. New Phytol. 2006; 74: 41-49.

[7] Suryatmana P, Anggraini DA, Kamaluddin NN, Setiawati MR. Nitrogen-fixing Bacteria inoculation (NFB) and Compost Application in Phytoremediation of Petroleum-Contaminated Soils using Ramie plant (Boehmeria nivea L). Int'l J Agric., Environ., Bioresearch. 2020; 5(04): 8-18.

[8] Boye VD, Boyld BJ. Nitrogen turnover in marine and brackish habitats. III. The production of extracellular nitrogen by Calothrix scopulorum. J. mar. Biol. 2006; 49: 475-488.

[9] Bone LK, Barr GD. An examination of some symbiotic system for fixation of nitrogen. Ann. Bot. 2000; 19: 67-77.

[10] Alexander VC, Billy GD, Schollar DM. The influence of abiotic factors on nitrogen fixation rates in the Barrow, Alaska tundra. Res. Stat. 2002; 11: 3-10.

[11] Cain NT, Edmund RT, Helen MB, Joseph WO. Nitrogen fixation in Swedish soils by blue green algae. New Phytol. 2006; 72: 504-601.

[12] Kamalu KI, Kamalu GD. Nitrogen fixation by Stereocaullon paschate under field conditions. Can. J. Bot. 2008; 55 : 582-590.

[13] Soibi GO. Nitrogen fixation by free-symbiotic Nostoc strain Isolated from Collema. Physiol. Plant. 2007; 4: 540545.

[14] Edward YO. In situ measurement of nitrogen fixation at low temperatures. Oikos. 2001; 25: 283-287.

[15] Meshack, MM, Mene BO. Stuches in the physiology of the lichen Collema. Physiol., Plant. 2001; 10: 947-950.

[16] Henshaw HJ, Kalio AT, Monday GD, John TJ. Nitrogen turnover in marine and brackish habitats. J. Mar. Biol. 2002; 49: 475-488.

[17] West SL, Benjamin JV. Saturated solutions for the control of humidity in biological research. Ecology. 2003; 41: 232-237.

[18] Stephen SL, Peace KJ. Nitrogen metabolism in lichens 1. Nitrogen fixation in the Cephalodia of Peltigera aphthosa. New Phytol. 2004; 68: 721-729. 
GSC Biological and Pharmaceutical Sciences, 2020, 13(01), 019-024

[19] Adejumo TO, Nally NM, Kate QV, Nketeli OJ. Nitrogen metabolism in lichen VI. The blue-green phycobiont contents heterocyst frequency and nitrogenase activity in Peltigera spp. New Phytol. 2005; 74: 473-476. 